\title{
Contemplating Sustainable Coastal Tourism in Balekambang Beach, Indonesia
}

\author{
Hengky, S. H. \\ Associate Professor, Dept. of Management, Bina Darma University, Indonesia \\ Director, Kent Polytechnic, Shine Institute \\ E-mail: hengky_halim@yahoo.com.au
}

Received: Dec. 19, 2016 Accepted: Dec. 25, 2016 Published: December 29, 2016

doi:10.5296/bms.v7i2.10523 URL: http://dx.doi.org/10.5296/bms.v7i2.10523

\begin{abstract}
Indonesia's tourism development continues to be encouraged for the sake of Indonesia made tourism the number one in the world. In fact, many people believe in tourism 2020 Indonesia so-world examples. The Minister of Tourism, believes the expected increase of 20 million travelers arrived in 2020. Along with the advent of globalization and the implementation of the ASEAN Economic Community, the District Government of Malang intends to develop coastal tourism, which is a source of income and constructed within the region, in particular, the field of tourism, in order to compete with other regions, not only domestically, but also abroad. This study aims, is to respond to the regent Malang's aims by contemplating sustainable coastal tourism in Balekambang beach. The result from this study is based on its concept indicating that these destinations are quite friendly environment with the gap of minimizing environment impacts and preserving its environment. The effort of preserve that environment shows the lowest performance on the existing condition. It's validated by the concern of minimizing an environmental impact, needs to be improved. The evidence shows from a previous story about it. Thereby, too many overlapping government-regulations in managing the using of the environment for tourism enterprises (coastal). In addition, utilization an environment for tourism is generally more concerned with the economic contribution to the treasury of the effort to control and sustainable environmental management.
\end{abstract}

Keywords: Sustainable-coastal tourism, Environment impact, Overlapping government-regulations 


\section{Introduction}

Indonesia's trip development is important to be a number-one tourism destination around the world. In fact, many people believe that Indonesia's tourism would be in the world example in 2020, and Tourism-Minister believes that the expected increase of 20 million tourists too. In terms of tourism, Indonesia could be a prototype in the world. For these achievements, including increasing the contribution of tourism in terms of employment and improving the quality of human resources continues to be added. Especially after the election of a new president and vice-president are later expected to bring Indonesia into the era of the gold that has never happened before (Widyaningsih, 2016).

To realize it, they called the revamping marketing, destination development, institutional and political, the budget must be done. Target tourist arrivals from China increased to 3.5 million people. So also in the framework of the ASEAN Economic community, Indonesia is targeting the number of travelers and seven million in 2020. To achieve these goals, the tourism industry is prepared to make Indonesia as a creative product that can reach global markets, ranging from hospitality, travel, merchandise, culinary Indonesia in order to compete regionally and globally.

Along with the advent of globalization and the implementation of the ASEAN Economic Community, the District Government of Malang intends to develop coastal tourism, which is a source of income and constructed within the region, in particular, the field of tourism, in order to compete with other regions, not only domestically, but also abroad. The regent expressed his desire to develop tourist destinations within the region he leads such as Lombok, West Nusa Tenggara, especially the county's coast, there are fewer beautiful beaches in Bali and Lombok. To realize his hopes, he makes planning and asphalting the road linking the southern cross on the Beach Sendangbiru Sumbemanjing District and Beach Balekambang in District Bantur, Malang, targeted for completion in 2016. It is expected that the tourism potential will also increase rapidly. Beautiful beaches can be enjoyed straight along the road, Malang.

Additionally, he also wants to develop tourism in Malang Regency is like Lombok is becoming a major tourist-destination for foreign tourists. If you want to pursue Bali, it's hard because Bali has been known for hundreds of years, while the destination just only known for the past 10 years. To become a mainstay tourist destination, Malang Regency own connectivity is qualified, like the flight path, supported by Abdul Rachman Saleh, a landline can be done by a train and sea lanes, get through the Port of Tanjung Perak Surabaya is located not far from Malang. He said the grand design will travel in Malang Regency is their sea travel will be equipped with a restaurant that utilizes worthy life boat, equipped pier on the beach which has a depth sufficient for reliance large boat (Asdhiana, 2016).

Nevertheless, one of the coastal tourism in Malang, namely Balekambang's beach is located on the Indian Ocean or the south coast whose presence in east Java's province. The beach is beginning to develop and heard his name and flew by tourists since 1978 after the opening an 
access road will be undertaken by the village head Srigonco named Tukiran. However, the beach was officially opened in 1983 and inaugurated by the regent of Malang. The beach was also a sloping area to be filled with sea coral that stretches along $2 \mathrm{~km}$ and has a width of 200 meters out to sea.

Shortly visit the sights of the beach is almost like travel in Bali is the land lot and another one that is in the province of Central-Java near the point where Mount Kidul Central-Java's province which Ngobaran Beach. The similarity of this travel the same as having buildings in the form as a temple in over rocks and is located along a shoreline. Therefore, this study aims, is to respond to the regent Malang's aims by contemplating sustainable coastal tourism in Balekambang beach.

\section{Literature Review}

Naturalness tourism along the coastlines is usually associated with a combination of properties, sea, sun, sand, beach, diversified culture, scenic beauty, food and healthy coastal seawater. Natural beach recreational activity is highly dependent on quality of ecosystems, landscapes, crafts and traditions. In addition to the physical condition, tourism management is also associated socio-economic and interest of the local population, environment, and local government policy (Edgell, 2016).

Process management of tourism in marine and coastal areas of complex related to the positive and negative effects on environments. The development of tourism can be modified with the consequences of the changes in the coastal-environment. Because it is necessary to integrate the unified management of tourism activities on developments. A framework for sustainable-development of coastal-tourism and its management zones is advised to consider the nature of the diversity of environments to promote the diversity of habitats and life forms along a beach. The management has been recognized by many tourism operators and decision-makers as a path to follow towards the sustainable development of beach tourism. Its management uses adaptive governance and multi-sector approach, which seeks to balance the utilization and protection of the coastal-environment. It is based on principles such as holistic approach and ecosystem-based, good governance, inter and intra-generational, keeping the peculiarities of the beach with the principles of prudence and prevention, which provide context to achieve the goals of sustainable-tourism (Lemmet \& Trumbic, 2009).

The government policy over the tips of environmental management of coastal tourism in reducing the negative environmental-impact in a sustainable manner that is useful in solving the problems of pollution and environmental-damage caused by the tourism activity. Similarly, Brake \& Addo (2014) states that the growth and impact of tourism activities. They found success factors and cultural development of environmental management in coastal-tourism. Hengky (2014) further explores the ways to improve competitiveness and preserve the coastal environment of reducing the negative impact, namely by making zoning and landscaping.

Coastal-tourism is one of the fastest-growing in the world tourism industry. In general, 
tourists come to the beach recreation associated with good development. However, such activity can cause negative effects on the coastal environment. These impacts are influenced by climate change. Therefore, Nara, Mao, \& Yen, (2014) showed that the environmental-impact is very important for beach recreation areas and greatly affected by proper environmental-management policy.

It implies, there are several challenges to adopt and implement responsible tourism management in mass tourism, because of the low understanding of a concept; lack of coordination and monitoring mechanisms, and a limited budget (Farmaki, Constanti, Yiasemi, $\&$ Karis, 2014). Sustainable tourism development is dominated by the theory of economic growth rather than protecting the environment. A key success implementation of the concept depends on the administrative structure of government bodies (Liu \& Mwanza, 2014).

At the same year, Anfuso, Williams, Hernandez \& Pranzini (2014) identified five types of sites' typology spectrum of the tourism zone. Class 1, of anthropogenic impacts are not dominant and occur in rural areas related to watering and sediment. Class 2, into international tourist destination characteristics of sand and good water. Class 3 and grade four medium attributes of natural and human resources and the water color are dark or brown with human intervention. Class 5 the lowest value in natural resources, erosion and degraded. A year earlier, Elvarsdottir (2013) observed the opportunities and challenges for a development and management of it to meet the needs, and the planning of protected areas.

Policy of coastal tourism can reduce the damage to the coastal-environment due to human activities. Success factors dependent on a development and environmental management. Based on a concept of sustainability, coastal tourism planning process is useful to reduce the level of damage ecological tourism area (Senlier \& Ozturk, 2011).

However, sustainable-coastal tourism should be managed by planning policies in a sustainable-manner that educate travellers and local communities all along the coast (Mavris 2011) by balancing economic growth, preserve the environment, minimize an environmental impact, and government policy will affect the pattern of planning and development tourism (Liu \& Mwanza, 2014).

\section{Methodology}

This study was conducted from November 2015 - November 2016 in Malang Regency, Indonesia by distributing 180 respondents and most of them on a coast-tourism activity. They are tour-guide, Association of Indonesia's travel agencies, Department of culture and tourism, Association of Indonesian Hotel and Restaurants, Department of Marine and Fisheries, travel agent, tourist bus' driver, local-resident along the coast, taxi and bus drivers, Front office's officers, merchants of local-food, domestic and international tourists, and local government staffs. Each respondent was questioned with three different times for their consistency (Jenning, 2001).

Based on sustainable coastal-tourism, collected data was tabulated by content analysis 


\section{Ml Macrothink}

(Gottschalk, 2013; and Cohen, 1960) that focus on planning policies in sustainable-manner, balancing economic activity, preserve the environment, minimized an environmental impact, government policy (Liu \& Mwanza, 2014; and Mavris, 2011).

Collected data in this research was systemized by using triangulation techniques that starting by observation, open interviews, secondary data analysis for verification (Marwick \& Uniger, 1975). Interview is strongly influenced by the situation of conducting it, interviewer's interest and topics, and respondent opinions. In general, content analysis tabulation of sustainable coastal-tourism explored analysis, posting each attribute, frequency counted, and discussion of existing and expected performance (UNEP \& WTO, 2012; and Smith, Scherre, \& Dowling, 2009).

\section{Discussion}

The result from this study is based on sustainable coastal tourism-indicating that these destinations are quite friendly environment (Table 1). The effort of preserve that environment shows the lowest performance on the existing condition. It's validated by the concern of minimizing an environmental impact, needs to be improved. The evidence shows from the previous story about it. Thereabout, too many overlapping government regulations in managing the use of environments for tourism enterprises (coastal). In addition, use of environments for tourism is generally more concerned with the economic contribution (Axioma \& Ardiwijaja, 2005) to the treasury of the effort to control and sustainable environmental management.

Table 1. Existing performance of sustainable coastal-tourism

\begin{tabular}{|l|c|c|}
\hline Sustainable Coastal-tourism in Balekambang & Value & \% Freq \\
\hline Government policy & 29 & 0.2636 \\
\hline Minimize an environmental impact & 26 & 0.2364 \\
\hline Economic Growth & 30 & 0.2727 \\
\hline Preserve the environment & 25 & 0.2273 \\
\hline Kappa Coefficient $=\mathrm{K}=0.6111$ & 0.6111 & \\
\hline
\end{tabular}

Furthermore, we observe the chronological inauguration of these destinations a few years back, according to history, the first time the beach is visited by the public in 1978, the opening access road leading through the beach is done by the village head increasingly attractive public at large and also regent who served at Malang that time, until the end of 1983, the beach was unveiled. It is located in the village Balekambang Beach "Srigonco" 
Bantur districts within 70 kilometers south of the city. There is no public transport here so travelers have to bring a personal vehicle or hire a vehicle from Kepanjen. "Balekambang" coast has a beautiful-beach that is not inferior to other beaches on the beach of eastern part of Java. The atmosphere is still beautiful. The beach is clean of dirt, and very attractive sunset makes this beach comfortable enjoyed. Long beach to 2 kilometers and a width of 200 meters makes you free run down the beach. When a low tide you can see a variety of corals and marine life that are being assembled. Wave on the beach is not too big.

"Balekambang" beach is in Malang city, East Java Province. Indeed, as we already know that the seashore having educational travel destinations, historical and natural tourist attraction also has a beach that is still well preserved. The coast, including one of the beaches in the district of Malang has a characteristic that is quite unique. The beach in the tourist area, travelers will find a special long bridge constructed to connect the temple building on a cliff by the shore. Besides the beach, it also offers beautiful white sand and quite shady. The shore sea waves big enough so the tourists are expected to be very careful if you want to swim or play water on a beach.

Not only on the island of Bali which is famous for the Land of a lot, at this beach was located in East Java also has a beach Balekambang with Sacred Hindu temple located in a giant rock that juts into the sea. The beach is administratively entered into the area of Malang, precisely in the village "Srigoco" in District Bantur. This attraction is not less great at Tanah Lot, mainly because there are white-sand beaches add to the scenic beauty of the oceans Balekambang Beach. If tourists come from Malang, then they only need a distance of about 70 kilometers. Fatigue will be paid once it gets to this attraction. Here they could spoil their eyes and relaxed the mind around the beach area. The beach has three islands whose unique rock was titled after characters within the puppet story, namely: Ismoyo Island, Hanuman, and Wisanggeni. On the island, there were Ismoyo Holy Temple and Beautiful buildings belonging to Hindus, Pura Jati Amerta or sometimes people call it a temple Ismoyo matched the name in which the temple is located. This temple is more like a temple. "Amerta" teak temple was built in 1985 on the orders of the unfortunate regent at the time. The design of the temple made such a lot of land in Bali. This temple would be crowded when the big day Hindus like "Suroan" and "Jalanidha Puja," for Hindus, temple is very sacred because the place is often used in religious-activities. This temple will look beautiful when the sun was setting.

In terms of traveler's activity, walking and driving around at this beach location is very attractive, especially in the late afternoon when the sun goes down, the tourists will see the view of the "sunset" magnificent with a background of golden temples and sky. Another activity that visitors can do in these places is swimming and playing water at a cost. However, because there is enough water in the Whirlpool and swift, the visitors are only allowed to swim in certain areas. Other facilities provided to area of attractions of this beach, there are souvenir shops, residences, public toilets, and there is much food stalls hawking East Javanese cuisine. If they arrive three days prior to Nyepi, then you can enjoy godly-tourism. 
On this beach, the community usually be held Hindu religious ceremonies by laying an offering to the sea. Definitely do not miss seeing the rare event was held at this beach.

Recently, the coast has become a favorite beach travel destination for tourists who visit the city of Malang, East Java. For tourists who like to enjoy the atmosphere of the beach, the beach that tourist must visit this one. Because it has a lot of beauty that is not inferior to other beaches in East Java. Most of them call this beach as the Land of the lot of East Java. Once on shore, they will be immediately offered a beautiful blue water, the waves and the typical beach panorama. The beach is somewhat of a clean beach and managed well. The atmosphere is quite calm can be a drug to reduce, or at least for a moment forget the burden of thinking that they are currently facing. In addition to panoramic waves and white sand, they can also enjoy several rows of islands across the beach, such as Wisanggeni Island, Island Anoman and Ismoyo Island, where the islands are connected by bridges.

Travelers can play near a sea with shallow beaches, and the waves are not so big, with their family or seeing a spacious variety of sea coral and sometimes when the tide, they can see a wide variety of fish, and other marine lives are clustered too. In addition, they can watch the local people, who still hold a ceremony Suroan usual tradition and ceremony of "Jalanidha Puja." If you have time, they can also visit this beach in the current month of Suro. Usually in this month, the beaches are crowded by tourists both domestic and foreign. Generally, they enjoyed the atmosphere very charming Balekambang beach at sunset arrives. Beauty and charm more spectacular as the Sun sets behind the horizon and presenting silhouettes against the sky temple twilight golden yellow, or they can play in the arena flying fox rides. In line with the market Dampit the trip to this beach, they can buy fish and squid to be burned at the seaside while they are waiting for a sunrise.

Besides being a place of worship of Hindus, the beach is an important place for Muslims too. "Suro" in Javanese calendar every month, Turkish Balekambang be the location of the ceremony and the ceremony Jalanidhi Suroan Puja ceremony. The beach will also be a religious tourist spot where the tomb of Sheikh Abdul Jalil artifacts. He is the man who first cleared the land or in Java's language is called tripe Balekambang Beach. Sheikh Abdul Jalil is a native of Yogyakarta and was buried in the tomb Balekambang within $1 \mathrm{~km}$ before entering the beach from the direction Bantur. On first of Sha'ban, the tomb of Sheikh Abdul Jalil Increasingly crowded with pilgrims.

After enjoying religious-tourism, travellers can watch the natural attractions the beach, sitting under a shady tree or play at a softly sand, and they can build sand castles or bury themselves in the sand. The Beach be an appropriate location for those who love camping or taking a family picnic too. There is also a modest bungalow scattered over the beach that they can use it in the rest. Even on weekends they can feel the game flying fox and motors All-Terrain-Vehicle. Other facilities provided at this beach are swings, pool, rooms, restaurants, souvenir stalls and a large parking area.

It can be seen from the Table 2 and Table 1 those expected performances of sustainable 
coastal-tourism is higher than existing performance. If we compared Kappa coefficient from 0.6111 to 0.7556 , it clearly that the predictable destination needs friendly government policy that will affect the pattern of planning and development beach-tourism.

As mentioned earlier, obviously the government policy needs to be transformed and aligned to the pattern of a tourism-plan, and it required to become more friendly-use on conservation and operation program (Table 3). These findings appear to suggest that government and travel agent need to be more care on minimizing an environmental impact as well as preserve the environment rather than economic growth (Rahman, 2016).

Table 2. Expected performance of sustainable coastal-tourism

\begin{tabular}{|l|c|c|}
\hline Sustainable Coastal-tourism in Balekambang & Value & \% Freq \\
\hline Government policy & 35 & 0.2574 \\
\hline Minimize an environmental impact & 33 & 0.2426 \\
\hline Economic Growth & 37 & 0.2721 \\
\hline Preserve the environment & 31 & 0.2279 \\
\hline Kappa Coefficient $=\mathrm{K}=0.7556$ & & \\
\hline
\end{tabular}

Table 3. Sustainable coastal-tourism's gaps

\begin{tabular}{|l|l|l|r|}
\hline Sustainable Coastal-tourism in Balekambang & \% Freq & \% Freq & Freq gaps \\
\hline Government policy & 0.2636 & 0.2574 & -0.0063 \\
\hline Minimize an environmental impact & 0.2364 & 0.2426 & 0.0063 \\
\hline Economic Growth & 0.2727 & 0.2721 & -0.0007 \\
\hline Preserve the environment & 0.2273 & 0.2279 & 0.0007 \\
\hline
\end{tabular}

In terms of its policy, conducting the management and governance of its strategy approach is needed tailoring to be environmental based, so that coastal tourism can be one pillar of the country's economy in a sustainable manner. In the management of tourism in view of the government must be responsive and take advantage of opportunities. In this regard, the government as the policy holder shall prepare a regulation / policy which is integrated in supporting the development of marine tourism. Mapping of coastal-tourism potential of value 
and characteristics of appropriate infrastructure, and is therefore determined that coast-tourism should be constructed and that only needs to be revitalized. After mapping the potential next step is to draw up an investment plan thus coastal tourism development plans are measurable and targeted.

At the same time, in terms of economic development, the contribution of coast-tourism in recent decades showed a positive trend in the development of the destination in Indonesia. The development of it shows multiple effects that can create jobs, increase incomes, increase foreign exchange and to encourage environmental conservation. Besides the development of seaside-tourism has a positive impact on growth and the rise to spirits and cultures of beach with it can provide numerous effects of encouraging a strong maritime nation.

Anyhow, these beaches have natural resources were very limited land, and have abundant seafaring resources. This is a strategic asset to be developed from the basis of economic activities in the utilization of natural resources and seagoing environmental services. In the development of industry, tourism and maritime transport, the potential need to be developed carefully and with an integrated approach between the potential of terrestrial, seaside and marine as well as an appropriate activity is absolutely necessary to avoid damage to the coastal environment (Asdhiana, 2016).

Therefore, the policy of coastal development areas should be tailored to the aspirations of the demands and expectations among the people that have been fused into cultural roots based on togetherness, the needs, and the ability of coast-communities to manage the utilization and development potential of existing resources, in order to improve the local economy in a sustainable-manner. Tourism's policy gets to support to a usages and development of a coastal-region should be able to avoid overlapping rules, strengthening the role of synergies between sectors, and with regard to the carrying capacity of the environment-oriented exploitation be sustainable rehabilitation.

Conditions' tourist destination today at scale four, which includes the condition of natural resources, and humans are pretty good and the color of dark or brown sea water due to human intervention. Based on Williams et al., (2014), this condition can be improved by implementing control programs based on utilization of coastal-environments empower communities to reduce the negative environmental-impact, and at the same time they participate in implementing environmental-conservation.

The principle of conservation in coastal-management implies that the existence of many parties contributed to an establishment of a system that ensures protection of environmental sustainability and ensures the quality of business activities and services in the coastal environment. This is done through management activities by paying more attention to the ecology and sensitive to social and cultural values of society. Therewith, determined carrying capacity, both socially and ecologically in order to minimize the negative impacts of development activities and beach tourism. 


\section{Conclusions}

The result from this study is based on its concept indicating that these destinations are quite friendly environment with the gap of minimizing environment impacts and preserving its environment. The effort of preserve that environment shows the lowest performance on the existing condition. It's validated by the concern of minimizing an environmental impact, needs to be improved. The evidence shows from a previous story about it. Thereby, too many overlapping government-regulations in managing the using of the environment for tourism enterprises (coastal). In addition, utilization an environment for tourism is generally more concerned with the economic contribution to the treasury of the effort to control and sustainable-environmental management.

\section{Implications}

It implies that the principle of conservation in coastal-management implies the existence of many parties contributed to an establishment of a system, which ensures protection of environmental sustainability and ensures the quality of business activities and services in the coastal environment.

Therefore, it needs more research on improving sustainable coastal-tourism by community empowerment on improving the performance of seaside-environment along the coastline.

\section{Acknowledgements}

The author would like to thank the anonymous reviewers for their helpful and constructive comments that greatly contributed in improving the final version of the paper. I would also like to thank the Editors for their generous comments and support during the review process.

\section{References}

Anfuso, G., Williams, A. T. Hernandez, J. A. C., \& Pranzini, E. (2014). Coastal scenic assessment and tourism management in western Cuba. Tourism Management, 42(2014), 307-320. http://dx.doi.org/10.1016/j.tourman.2013.12.001

Asdhiana, I. M. (2016). Hard to Pursue Bali, Malang Tourism Want Lombok, KOMPAS.com. Retrived from http://internasional.kompas.com/read/2016/07/25/121100927/Susah.Kejar.Bali.Pariwisata.Ma lang.Ingin.seperti.Lombok

Axioma, A. D., \& Ardiwijaja, R. (2005). Tourism Sustainable Development: An Analysis Policy, Pembangunan Pariwisata, 8(1), 29-40. Retrieved from http://dspace.library.uph.edu:8080/bitstream/123456789/2866/1/jiuph-08-01-2005-pengemba ngan_pariwisata_berkelanjutan_sebuah.pdf

Brake, W., \& Addo, E. (2014). Tourism and Fracking in Western Newfoundland: Interests and Anxieties of Coastal Communities and Companies in the Context of Sustainable Tourism. International Journal of Marine Science, 4(2), 16-41. 
http://dx.doi.org/10.5376/ijms.2014.04.0002

Cohen, J. (1960). A Coefficient of Agreement for Nominal Scales. Educational and Psychological, 20, 37-46. http://dx.doi.org/10.1177/001316446002000104

Edgell, D. L. (2016). Managing Sustainable Tourism: A Legacy for the Future, Routledge, 231-235.

Elvarsdottir, H. S. (2013). An Approach towards sustainable tourism management: nature-based tourism in Nuup Kangertua, Greenland. Coastal and Marine Management, (Thesis). Retrieved from http://hdl.handle.net/1946/15833

Farmaki, A., Constanti, P., Yiasemi, I., \& Karis, P. (2014). Responsible tourism in Cyprus: the rhetoric and the reality. Worlwide Hospitality and Tourism Themes, 6(1), 10-26. http://dx.doi.org/10.1108/WHATT-10-2013-0041

Gottschalk, L. A. (2013). Content Analysis of Verbal Behavior: New Findings and Clinical Applications, Routledge, 19-22

Hengky, H. S. (2014). Excogitated Coastal Tourism Competitiveness by Implementing Eco-tourism in Anyer, Banten, Indonesia. International Journal of Marine Science, 4(7), 74-81. http://dx.doi.org/10.5376/ijms.2014.04.0007

Jenning, G. (2001). Tourism Research, John Willey \& Sons Australia, Ltd., 136-152

Kutesa, S. K. (2015). Transforming Our World: The 2030 Agenda For Sustainable Development, INFID. 104-110. Retrieved from http://infid.org/wp-content/uploads/2016/01/Outcome-Document-SDGs-Bahasa-Indonesia-_u tk-konferensi.pdf

Lemmet, S., \& Trumbic, V. (2009). Sustainable Coastal Tourism, An integrated planning and management approach, United Nations Environment Programme, 2-4. Retrieved from http://www.unep.org/pdf/DTIE_PDFS/DTIx1091xPA-SustainableCoastalTourism-Planning.p df

Liu, B., \& Mwanza, F. M. (2014). Towards sustainable tourism development in Zambia: Advancing tourism planning and natural resource management in Livingstone (Mosi-ao-Tunya) Area. Journal of Service Science and Management, 7(1), 30-45. http://dx.doi.org/10.4236/jssm.2014.71004

Marwick D. P., \& Uniger, C. H. (1975). The Sample Survey, Theory and Practice, Mc Graw Hill Book Co, New York.

Mavris, C. (2011). Sustainable Environmental Tourism and Insular Coastal Area Risk Management in Cyprus and the Mediterranean. Journal of Coastal Research: Special Issue 61, 317 - 327. http://www.jcronline.org/doi/pdf/10.2112/SI61-001.32

Nara, P., Mao, G., \& Yen, T. (2014). Applying Environmental Management Policy for 


\section{Macrothink}

Sustainable Development of Coastal Tourism in Thailand. International Journal of Environmental Protection and Policy, 1, 19-23. http://dx.doi.org/10.11648/j.ijepp.20140201.13

Rahman, A. (2016). Tourism As An Economic Pillar, Kompasiana. Retrieved from http://www.kompasiana.com/aulia45/pariwisata-sebagai-sebuah-pilar-ekonomi_552838096ea 834ea068b45da

Senlier, N., \& Ozturk, G. (2011). Investigation of Fragility to Estimate Tourism Pressure. Journal of Coastal Research, 217-220. http://www.jcronline.org/doi/pdf/10.2112/SI61-001.17

Smith A.J., Scherre P., \& Dowling R. (2009) Impacts on Aboriginal spirituality and culture from tourism in the coastal waterways of Kimberly region, North West Australia. Journal of Ecotourism, 8(2), 82-98. http://dx.doi.org/10.1080/14724040802696007

UNEP \& WTO (2012). Tourism in the Green Economy - Background Report, United Nations Environment Programme and World Tourism Organization, UNWTO, Madrid

Widyaningsih, S. (2016). Research and Tourism Industry Data 2010-2020, industrialized world. Retrieved from http://duniaindustri.com/downloads/riset-dan-data-industri-pariwisata-2010-2020/

\section{Copyright Disclaimer}

Copyright for this article is retained by the author(s), with first publication rights granted to the journal.

This is an open-access article distributed under the terms and conditions of the Creative Commons Attribution license (http://creativecommons.org/licenses/by/3.0/). 